\title{
tale-Based Genetic Diversity of Chinese Isolates of the Citrus Canker Pathogen Xanthomonas citri subsp. citri
}

Gang Ye and Ni Hong, National Key Laboratory of Agromicrobiology, Huazhong Agricultural University, Wuhan, Hubei 430070, China; Li-Fang Zou, Hua-Song Zou, and Muhammad Zakria, School of Agriculture and Biology, Shanghai Jiao Tong University, Shanghai 200240, China; Guo-Ping Wang, National Key Laboratory of Agromicrobiology, Huazhong Agricultural University; and Gong-You Chen, School of Agriculture and Biology, Shanghai Jiao Tong University

\begin{abstract}
Ye, G., Hong, N., Zou, L.-F., Zou, H.-S., Zakria, M., Wang, G.-P., and Chen, G.-Y. 2013. tale-Based genetic diversity of Chinese isolates of the citrus canker pathogen Xanthomonas citri subsp. citri. Plant Dis. 97:1187-1194.

Pathotype A of Xanthomonas citri subsp. citri, the cause of citrus bacterial canker $(\mathrm{CBC})$, is assumed to have originated in southern China. PthA, a type III secreted transcriptional activator-like effector (TALE), is a major pathogenicity determinant in X. citri subsp. citri. To investigate the diversity of $X$. citri subsp. citri in China, genomic and plasmid DNA of $105 \mathrm{X}$. citri subsp. citri isolates, collected from nine citrus-growing provinces of China, were digested by BamHI and hybridized with an internal repeat region of $p t h A$. Strains were classified into 14 different genotypes (designated $\mathrm{A}$ to $\mathrm{N}$ ) based on the number

$62 \%$ of the isolate collection, respectively. Genotypes $\mathrm{J}$ and L lacked pthA or a pthA-hybridizing fragment and were less virulent on grapefruit $(C$. paradisi) and sweet orange $(C$. sinensis) compared with strains containing pthA or a pthA homologue. The virulence of genotypes $\mathrm{J}$ and $\mathrm{L}$ was increased when the wild-type $p t h A$ was introduced. Genotype I, which was isolated from sweet orange in Jiangxi province, caused typical canker symptoms and may contain a novel pthA-like gene. To our knowledge, this is the first description of genetic diversity in Chinese CBC strains based on tale gene analysis.
\end{abstract} and size of pthA homologues. Genotypes B and G represented 19 and
Citrus bacterial canker (CBC) is one of the most economically important diseases of citrus in tropical and subtropical countries $(9,17)$. Characteristic symptoms of CBC include the formation of necrotic, raised lesions on leaves, twigs, stems, and fruit. When the disease is severe, the pathogen can cause defoliation, twig dieback, decline, and premature fruit drop $(18,37)$. The geographical origin of CBC is controversial. It is assumed that the disease may have originated in southern China with Fortunella hindsii as the wild host (24). In contrast, there are reports that CBC may have originated from India or Java $(14,21,27)$. In geographical areas without $\mathrm{CBC}$, the pathogen is considered a quarantine pest due to its potential threat to citrus production and food safety (18).

It is widely accepted that Xanthomonas citri subsp. citri $(13,36)$ is one of the most devastating pathogens of commercial citrus. However, bacteria associated with $\mathrm{CBC}$ have been divided into different pathotypes based on host range and symptomology. These include pathotypes A (X. axonopodis pv. citri), B/C/D (X. axonopodis pv. aurantifolii), and $\mathrm{E}$ (X. axonopodis pv. citrumelo) $(18,35,42)$. Three separate taxa-X. smithii subsp. citri, $X$. fuscans subsp. aurantifolii, and $X$. alfalfae subsp. citrumelo-are currently classified as X. citri (pathotype A), X. fuscans (B/C/D), and $X$. alfalfae (E) (39). Pathotype A, which is the Asiatic form of CBC, has a wide host range and is pathogenic on almost all citrus varieties. Pathotype A contains $p t h A$ or $p t h A$ homologues; $p t h A$ is a major virulence gene and encodes a type III secreted transcriptional activator-like effector (TALE) that promotes cellular hypertrophy $(1,12,40,41)$.

TALEs are a structurally and functionally distinct class of proteins present in the Hrp II group of plant-pathogenic bacteria. TALE proteins are translocated into plant nuclei, bind to TALE-

Corresponding authors: G.-Y. Chen and G.-P. Wang,

E-mail: gyouchen@sjtu.edu.cn and gpwang@mail.hzau.edu.cn

Accepted for publication 16 March 2013.

http://dx.doi.org/10.1094/PDIS-12-12-1201-RE

(C) 2013 The American Phytopathological Society specific DNA coding regions, and activate transcription of downstream genes for disease susceptibility or resistance $(2,4,11,22,30$ 32). These statements are based on studies of AvrBs3, a TALE protein produced by the pepper and tomato pathogen $X$. campestris pv. vesicatoria (5). TALEs share several common features, including an $\mathrm{N}$-terminal region required for secretion via the type III secretion system, a C-terminus containing nuclear localization signals, and an acidic activation domain typical of transcription factors. TALEs contain a central domain of tandem, nearly identical 33- to 34-amino-acid repeats that confer DNA-binding specificity $(1,38,46)$. The number of repeats varies among TALEs, and the residues at the 12 th and 13 th positions are hypervariable and known as repeat-variable diresidues (RVDs). The RVDs bind to specific, single nucleotides and, consequently, determine specificity for disease susceptibility or resistance $(2,4,31)$. Within the host cell, TALEs bind DNA at up-regulated by TALE boxes, a region that is not described for PthA (or PthA homologues) and citrus. The identification of new pthA-homologues in $X$. citri subsp. citri strains could advance efforts to understand this phenomenon.

There are many approaches to differentiate pathogens associated with $\mathrm{CBC}$, including physiological and serological tests, phage typing, restriction enzyme analysis, total soluble protein profiles, and polymerase chain reaction (PCR)-based methods $(15,16,19$, 20,29,33,43,45). However, the differentiation of pathogen strains by these methods is not linked with virulence factors. To address this issue, a pthA-based PCR strategy to rapidly and sensitively detect CBC strains has been developed (34). However, the number of pthA homologues in different strains is not known and warrants further investigation. The genome sequence of a typical CBC strain (e.g., X. citri subsp. citri 306) revealed the presence of four plasmid-encoded tale genes, including pthA (10). X. citri subsp. citri strains from Korea were grouped into 13 genotypes based on pthA hybridization studies (25). Although the identification of tale genes in $\mathrm{CBC}$ strains may reveal potential interactions with citrus, the diversity of tale genes has not been studied in China, where CBC pathogens presumably originated (27).

The objective of the current study was to evaluate the distribution of tale genes in $X$. citri subsp. citri strains from China. This 
was undertaken by collecting isolates from nine citrus-growing provinces and investigating the number and size of tale genes by hybridization analysis using $p t h A$ as a probe.

\section{Materials and Methods}

Isolation of bacterial strains. Samples of Citrus sinensis, $C$. reticulata, C. paradisi, C. unshiu, Fortunella margarita, and Poncirus trifoliata with CBC symptoms were collected from nine citrus-growing provinces in southern China from 2008 to 2011 (Table 1). Diseased tissues were surfaced sterilized and crushed in $1 \mathrm{ml}$ of sterile distilled water $\left(\mathrm{dH}_{2} \mathrm{O}\right)$ using a glass rod. Samples were plated in nutrient agar (NA) (28) and incubated at $28^{\circ} \mathrm{C}$ for 3 days. Yellow bacterial colonies were consistently isolated. Purified isolates were obtained from single colonies and analyzed by PCR using the $X$. citri subsp. citri-specific primers $J$-pthl and $J$-pth2
(8). Isolates were maintained at $-80^{\circ} \mathrm{C}$ in fresh nutrient broth containing $25 \%$ glycerol.

Potential pathogenicity of isolates was screened in hypersensitive response (HR) assays. Bacterial suspensions $1 \times 10^{8} \mathrm{CFU} / \mathrm{ml}$ in $\mathrm{dH}_{2} \mathrm{O}$ ) were infiltrated into tomato (Lycopersicon esculentum var. esculentum) and tobacco (Nicotiana benthamiana) leaves. Infiltration assays were repeated three times. Isolates producing an HR were deemed pathogenic and were later used for pathogenicity assay in citrus.

Southern hybridizations. Total genomic DNA was extracted from bacteria using the cetyltrimethylammonium bromide method, as described previously (3). DNA samples $(3 \mu \mathrm{g})$ were digested with $\mathrm{BamHI}$ at $37^{\circ} \mathrm{C}$ for $4 \mathrm{~h}$, separated in $1.2 \%$ agarose gels, and then transferred to Hybond $\mathrm{N}^{+}$nylon membranes. The probe was a digoxigenin-labeled 2.3-kb internal SphI fragment of pthA (Gen-

Table 1. Genotype and virulence analysis of Xanthomonas citri subsp. citri isolates from China

\begin{tabular}{|c|c|c|c|c|c|}
\hline \multirow[b]{2}{*}{ Strains } & \multirow[b]{2}{*}{ tale Genes $^{\mathrm{z}}$} & \multirow[b]{2}{*}{ Genotype } & \multicolumn{2}{|c|}{ Virulence $^{y}$} & \multirow[b]{2}{*}{ Origin (cultivar, area) } \\
\hline & & & Grapefruit & Sweet orange & \\
\hline$\overline{1}$ & 5 & $\mathrm{G}$ & ++ & ++ & Citrus unshiu, Jiangxi \\
\hline 2 & 5 & $\mathrm{G}$ & ++ & ++ & C. sinensis, Jiangxi \\
\hline 3 & 5 & A & ++ & ++ & C. paradisi, Guangdong \\
\hline 4 & 5 & $\mathrm{G}$ & ++ & ++ & C. sinensis, ZheJiang \\
\hline 5 & 5 & $\mathrm{G}$ & ++ & ++ & C. sinensis, ZheJiang \\
\hline 6 & 4 & B & ++ & ++ & C. sinensis, Guangxi \\
\hline 7 & 5 & $\mathrm{G}$ & ++ & ++ & C. sinensis, Guangxi \\
\hline 8 & 5 & G & ++ & ++ & C. sinensis, Guangxi \\
\hline 9 & 4 & $\mathrm{~B}$ & ++ & ++ & C. sinensis, Guangxi \\
\hline 10 & 5 & $\mathrm{G}$ & ++ & ++ & C. sinensis, Jiangxi \\
\hline 11 & 5 & G & ++ & ++ & C. sinensis, Jiangxi \\
\hline 12 & 6 & $\mathrm{D}$ & ++ & ++ & C. sinensis, Jiangxi \\
\hline 13 & 5 & G & ++ & ++ & C. sinensis, Jiangxi \\
\hline 14 & 5 & $\mathrm{G}$ & ++ & ++ & C. sinensis, Jiangxi \\
\hline 15 & 5 & $\mathrm{C}$ & ++ & ++ & C. sinensis, Jiangxi \\
\hline 16 & 5 & $\mathrm{G}$ & ++ & ++ & C. sinensis, Jiangxi \\
\hline 17 & 5 & $\mathrm{G}$ & ++ & ++ & C. sinensis, Jiangxi \\
\hline 18 & 5 & G & ++ & ++ & C. sinensis, Jiangxi \\
\hline 19 & 5 & $\mathrm{E}$ & ++ & ++ & C. sinensis, Jiangxi \\
\hline 20 & 5 & $\mathrm{G}$ & ++ & ++ & C. sinensis, Guangxi \\
\hline 21 & 4 & $\mathrm{~F}$ & ++ & ++ & C. sinensis, Jiangxi \\
\hline 22 & 5 & $\mathrm{G}$ & ++ & ++ & C. sinensis, Jiangxi \\
\hline 23 & 5 & G & ++ & ++ & C. sinensis, Jiangxi \\
\hline 24 & 5 & G & ++ & ++ & C. sinensis, Jiangxi \\
\hline 25 & 5 & G & ++ & ++ & C. sinensis, Jiangxi \\
\hline 26 & 5 & $\mathrm{G}$ & ++ & ++ & C. sinensis, Jiangxi \\
\hline 27 & 4 & $\mathrm{H}$ & ++ & ++ & C. sinensis, Jiangxi \\
\hline 28 & 4 & $\mathrm{H}$ & ++ & ++ & C. sinensis, Jiangxi \\
\hline $029-1$ & 5 & I & ++ & ++ & C. sinensis, Jiangxi \\
\hline $029-2$ & 5 & $\mathrm{~J}$ & + & + & C. sinensis, Jiangxi \\
\hline 30 & 5 & $\mathrm{G}$ & ++ & ++ & C. sinensis, Jiangxi \\
\hline 31 & 5 & $\mathrm{G}$ & ++ & ++ & C. sinensis, Jiangxi \\
\hline 32 & 5 & I & ++ & ++ & C. sinensis, Jiangxi \\
\hline 33 & 5 & G & ++ & ++ & C. sinensis, Jiangxi \\
\hline 34 & 5 & I & ++ & ++ & C. paradisi, Jiangxi \\
\hline 35 & 5 & I & ++ & ++ & C. sinensis, Jiangxi \\
\hline 36 & 5 & $\mathrm{G}$ & ++ & ++ & C. sinensis, Jiangxi \\
\hline 37 & 5 & $\mathrm{G}$ & ++ & ++ & C. sinensis, Jiangxi \\
\hline 38 & 5 & $\mathrm{G}$ & ++ & ++ & P. trifoliata, Jiangxi \\
\hline 39 & 4 & $\mathrm{~B}$ & ++ & ++ & C. sinensis, ZheJiang \\
\hline 40 & 4 & B & ++ & ++ & C. sinensis, ZheJiang \\
\hline 41 & 4 & $\mathrm{~B}$ & ++ & ++ & C. sinensis, ZheJiang \\
\hline 42 & 5 & $\mathrm{~K}$ & ++ & ++ & C. paradisi, ZheJiang \\
\hline 43 & 5 & $\mathrm{~K}$ & ++ & ++ & C. paradisi, ZheJiang \\
\hline 44 & 5 & $\mathrm{G}$ & ++ & ++ & C. paradisi, ZheJiang \\
\hline 45 & 5 & $\mathrm{G}$ & ++ & ++ & C. paradisi, ZheJiang \\
\hline 46 & 5 & $\mathrm{~K}$ & ++ & ++ & C. sinensis, ZheJiang \\
\hline 47 & 5 & $\mathrm{G}$ & ++ & ++ & C. sinensis, ZheJiang \\
\hline 48 & 5 & $\mathrm{G}$ & ++ & ++ & C. sinensis, ZheJiang \\
\hline 49 & 3 & $\mathrm{~L}$ & + & + & C. sinensis, ChongQing \\
\hline & & & & & (continued on next page) \\
\hline
\end{tabular}

\footnotetext{
${ }^{y}$ Symbols: ++ indicates full virulence, where normal canker symptoms formed in the tested citrus cultivars; otherwise, + indicates reduced virulence.

${ }^{\mathrm{z}}$ Number of transcriptional activator-like effector (tale) genes in a strain was putatively figured out according to the hybridized bands displayed in Figure 2 . It was assumed that there were two tale genes in a band which was more heavily hybridized than the upper and lower bands when the BamHI-digested genomic DNA of a strain was hybridized with the internal $S p h$ I fragment of $p t h A$ as the probe.
} 
Bank accession number U28802.1) originating from $X$. citri subsp. citri strain 3213 (41). This 2.3-kb SphI fragment of pthA contains 17.5 tandem repeats of a 102-bp sequence and part of the leucine zipper coding region (Fig. 1) (38). The internal SphI fragment of the pthA gene, which was cloned in plasmid pZit45 (provided by Dr. Yong-Ping Duan) (1), was used as a probe to detect the number and size of tale genes in each strain. Labeling, hybridization, and detection procedures were performed as recommended by the manufacturer (Roche) and repeated twice.

Complementation studies with pthA. The sequences flanking the upstream and downstream of the BamHI sites are almost identical in the tale genes of $X$. oryzae pv. oryzae strain KACC10331 (23) and X. citri subsp. citri strain 306 (10). In an attempt to complement Chinese $X$. citri subsp. citri strains lacking $p$ thA, the 3.4$\mathrm{kb}$ BamHI fragment of pthA in pZit45 was subcloned into
pUAVPD, replacing the 2.4-kb BamHI fragment of avrXa3 (46) and generating the recombinant plasmid pPthA. After confirmation by sequence analysis, this plasmid was transferred into $X$. citri subsp. citri strains 029-2 and 049, which lack a 3.4-kb homologue of pthA. Recombinant $X$. citri subsp. citri strains containing pPthA were selected on NA with kanamycin. Putative recombinants were then verified by PCR amplification with the pPthA-specific primers $J$-pth1 and $J$-pth2 $(8,48)$ and designated X. citri subsp. citri strains 029-2(pPthA) and 049(pPthA), respectively.

Pathogenicity assays and bacterial growth in planta. Citrus (C. paradisi, grapefruit and $C$. sinensis, sweet orange) plants were raised in pots under greenhouse conditions to establish the pathogenicity of $X$. citri subsp. citri strains $(1,18,38,39,47)$. X. citri subsp. citri strains were grown for 2 days on NA at $28^{\circ} \mathrm{C}$ and then suspended in sterile distilled water. Bacterial suspensions $\left(1 \times 10^{8}\right.$

Table 1. (continued from preceding page)

\begin{tabular}{|c|c|c|c|c|c|}
\hline \multirow[b]{2}{*}{ Strains } & \multirow[b]{2}{*}{ tale Genes ${ }^{\mathrm{z}}$} & \multirow[b]{2}{*}{ Genotype } & \multicolumn{2}{|c|}{ Virulence $^{y}$} & \multirow[b]{2}{*}{ Origin (cultivar, area) } \\
\hline & & & Grapefruit & Sweet orange & \\
\hline 50 & 4 & $\mathrm{~B}$ & ++ & ++ & C. sinensis, ChongQing \\
\hline 51 & 4 & $\mathrm{~B}$ & ++ & ++ & C. sinensis, ChongQing \\
\hline 52 & 5 & $\mathrm{G}$ & ++ & ++ & C. sinensis, Jiangxi \\
\hline 53 & 5 & $\mathrm{G}$ & ++ & ++ & C. sinensis, Jiangxi \\
\hline 54 & 5 & $\mathrm{G}$ & ++ & ++ & C. sinensis, Jiangxi \\
\hline 55 & 5 & $\mathrm{G}$ & ++ & ++ & C. sinensis, Jiangxi \\
\hline 56 & 5 & G & ++ & ++ & C. sinensis, Jiangxi \\
\hline 57 & 5 & $\mathrm{G}$ & ++ & ++ & C. sinensis, Jiangxi \\
\hline 58 & 5 & $\mathrm{G}$ & ++ & ++ & C. sinensis, Jiangxi \\
\hline 59 & 5 & $\mathrm{G}$ & ++ & ++ & C. reticulata, Guangdong \\
\hline 60 & 5 & $\mathrm{G}$ & ++ & ++ & C. reticulata, Guangdong \\
\hline 61 & 5 & $\mathrm{G}$ & ++ & ++ & C. reticulata, Guangdong \\
\hline 62 & 4 & B & ++ & ++ & C. reticulata, Guangdong \\
\hline 63 & 4 & $\mathrm{~B}$ & ++ & ++ & C. reticulata, Guangdong \\
\hline 64 & 4 & $\mathrm{~B}$ & ++ & ++ & C. reticulata, Guangdong \\
\hline 65 & 4 & $\mathrm{~B}$ & ++ & ++ & C. reticulata, Guangdong \\
\hline 66 & 4 & B & ++ & ++ & C. reticulata, Guangdong \\
\hline 67 & 4 & $\mathrm{~B}$ & ++ & ++ & C. reticulata, Guangdong \\
\hline 68 & 4 & $\mathrm{~B}$ & ++ & ++ & C. reticulata, Guangdong \\
\hline 69 & 4 & $\mathrm{~B}$ & ++ & ++ & C. reticulata, Guangdong \\
\hline 70 & 4 & $\mathrm{~B}$ & ++ & ++ & C. reticulata, Guangdong \\
\hline 71 & 5 & $\mathrm{G}$ & ++ & ++ & C. reticulata, Guangdong \\
\hline 72 & 4 & $\mathrm{~B}$ & ++ & ++ & C. reticulata, Guangdong \\
\hline 73 & 5 & $\mathrm{G}$ & ++ & ++ & C. reticulata, Guangdong \\
\hline 74 & 4 & $\mathrm{~B}$ & ++ & ++ & C. sinensis, Zhejiang \\
\hline 75 & 5 & $\mathrm{G}$ & ++ & ++ & C. sinensis, Zhejiang \\
\hline 76 & 5 & $\mathrm{G}$ & ++ & ++ & C. sinensis, Zhejiang \\
\hline 77 & 4 & $\mathrm{~B}$ & ++ & ++ & C. sinensis, Zhejiang \\
\hline 78 & 5 & $\mathrm{G}$ & ++ & ++ & C. sinensis, Zhejiang \\
\hline 79 & 5 & G & ++ & ++ & C. sinensis, Zhejiang \\
\hline 80 & 5 & G & ++ & ++ & C. reticulata, Fujian \\
\hline 81 & 5 & $\mathrm{G}$ & ++ & ++ & C. reticulata, Fujian \\
\hline 82 & 5 & M & ++ & ++ & C. sinensis, Hubei \\
\hline 83 & 5 & M & ++ & ++ & C. sinensis, Hubei \\
\hline 84 & 5 & M & ++ & ++ & C. sinensis, Hubei \\
\hline 85 & 5 & G & ++ & ++ & Fortunella margarita, Guangxi \\
\hline 86 & 5 & $\mathrm{~N}$ & ++ & ++ & F. margarita, Guangxi \\
\hline 87 & 5 & $\mathrm{G}$ & ++ & ++ & C. sinensis, Jiangxi \\
\hline 88 & 5 & G & ++ & ++ & C. sinensis, Jiangxi \\
\hline 89 & 5 & $\mathrm{G}$ & ++ & ++ & C. unshiu, Zhejiang \\
\hline 90 & 5 & $\mathrm{G}$ & ++ & ++ & C. unshiu, Zhejiang \\
\hline 91 & 5 & G & ++ & ++ & C. unshiu, Zhejiang \\
\hline 92 & 5 & $\mathrm{G}$ & ++ & ++ & C. sinensis, Guizhou \\
\hline 93 & 5 & $\mathrm{G}$ & ++ & ++ & C. sinensis, Guizhou \\
\hline 94 & 4 & $\mathrm{~B}$ & ++ & ++ & C. sinensis, Guizhou \\
\hline 95 & 5 & $\mathrm{G}$ & ++ & ++ & C. sinensis, Guizhou \\
\hline 96 & 5 & $\mathrm{G}$ & ++ & ++ & C. sinensis, Guizhou \\
\hline 97 & 5 & $\mathrm{G}$ & ++ & ++ & C. sinensis, Guizhou \\
\hline 98 & 5 & G & ++ & ++ & C. sinensis, Guizhou \\
\hline 99 & 5 & G & ++ & ++ & C. sinensis, Guizhou \\
\hline 100 & 5 & $\mathrm{G}$ & ++ & ++ & C. sinensis, Guangdong \\
\hline 101 & 5 & $\mathrm{G}$ & ++ & ++ & C. sinensis, Guangdong \\
\hline 102 & 5 & $\mathrm{G}$ & ++ & ++ & C. sinensis, Guangdong \\
\hline 103 & 5 & G & ++ & ++ & C. sinensis, Hunan \\
\hline 104 & 5 & $\mathrm{G}$ & ++ & ++ & C. sinensis, Hunan \\
\hline
\end{tabular}


$\mathrm{CFU} / \mathrm{ml}$ ) were injected into the intercellular spaces of fully expanded citrus leaves with needleless syringes. Inoculated plants were maintained in a greenhouse under a temperature regimen of $28^{\circ} \mathrm{C}$ (day) and $25^{\circ} \mathrm{C}$ (night). Twelve days after inoculation, the aggressiveness of each strain was evaluated by assessing the appearance of water-soaked margins. To measure bacterial growth in planta, leaf disks $(0.8 \mathrm{~cm}$ in diameter $)$ were excised with a cork borer and macerated in $1 \mathrm{ml}$ of $\mathrm{dH}_{2} \mathrm{O}$. Macerated leaves were serially diluted, plated on NA, and incubated at $28^{\circ} \mathrm{C}$ for 3 days. The CFU per square centimeter of leaf tissue was calculated at $0,2,4$, $6,8,10$, and 12 days post inoculation (26). All of the tests above were repeated three times independently.

\section{Results}

Isolation of $\boldsymbol{X}$. citri subsp. citri. Strains were identified as $X$. citri subsp. citri by PCR (Table 1) and confirmed to induce an HR

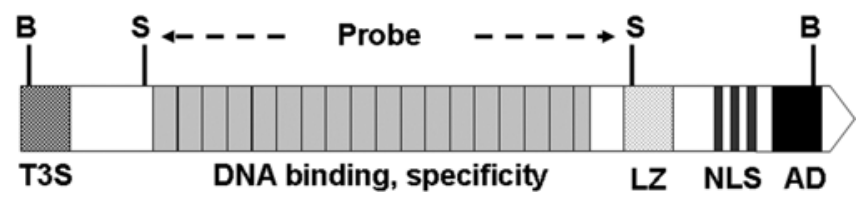

Fig. 1. Functional map of conserved regions in transcriptional activator-like effector (TALE) family members of Xanthomonas citri subsp. citri as represented by PthA. Abbreviations: B and S indicate BamHI and Sphl sites in pthA, respectively. The horizontal dashed line between the two Sphl sites indicates the location of the probe, which is a 2.3-kb fragment containing 17.5 repeats of a 102-bp sequence involved in PthA specificity. T3S represents the secretion signal at the $\mathrm{N}$-terminus of TALEs that is responsible for secretion via the type III secretion system; LZ = leucine zipper, NLS = nuclear localization signal, and AD = an acidic transcriptional activation domain. in tomato and tobacco. The number of strains isolated from the different provinces was as follows: Jiangxi, 40; Zhejiang, 21; Guangdong, 19; Guizhou, 8; Guangxi, 7; Chongqing, 3; Hubei, 3; Hunan, 2; and Fujian, 2 (Table 2). The strains were isolated primarily from C. sinensis $(71.43 \%)$, C. reticulata $(16.19 \%)$, C. paradisi (5.71\%), C. unshiu (3.81\%), F. margarita (1.91\%), and P. trifoliata $(0.95 \%)$ (Table 3). Pathogenicity was assessed in grapefruit and sweet orange. $X$. citri subsp. citri strains 029-2 and 049, which were originally isolated from $C$. sinensis, showed reduced virulence on both grapefruit and sweet orange (Table 1), suggesting a potential genetic variation in virulence compared with the other 103 strains.

Chinese strains of $X$. citri subsp. citri are classified into 14 genotypes. All strains contained multiple fragments homologous to the SphI fragment of pthA (Fig. 2). The largest and smallest hybridizing bands were approximately 4.6 and $2.0 \mathrm{~kb}$, respectively (Figs. 2 and 3), suggesting that the potential tale genes contain either more or fewer 102-bp repeat units than pthA. Some bands hybridized more intensely to the probe and may possibly contain at least two similar tale genes, such as the $3.2-\mathrm{kb}$ heavily hybridized band in $X$. citri subsp. citri 006 (Figs. 2 and 3). Thus, the putative tale genes of each $X$. citri subsp. citri isolates (Table 1) were calculated one more than the hybridized bands if an intensively hybridized band existed correspondingly (Figs. 2 and 3). The Chinese strains generally contained four to six bands with homology to the probe, suggesting the presence of multiple tale genes in all 105 strains. Because the tale genes are highly conserved, the size variation of hybridizing bands presumably represents the number of 102-bp internal repeat units (Fig. 1). Based on the results in Figure 2, the strains were classified into 14 genotypes designated $\mathrm{A}$ to $\mathrm{N}$ (Table 1; Fig. 3). Notably, the strains isolated from $C$. sinensis

Table 2. Genotypes of isolates collected from different provinces of China

\begin{tabular}{|c|c|c|c|c|c|c|c|c|c|c|c|c|c|c|c|}
\hline \multirow[b]{2}{*}{ Location } & \multicolumn{14}{|c|}{ Genotype $^{w}$} & \multirow[b]{2}{*}{ Total $^{\mathrm{x}}$} \\
\hline & $\mathbf{A}$ & B & $\mathbf{C}$ & D & $\mathbf{E}$ & $\mathbf{F}$ & G & $\mathbf{H}$ & I & $\mathbf{J}$ & $\mathbf{K}$ & $\mathbf{L}$ & $\mathbf{M}$ & $\mathbf{N}$ & \\
\hline Jiangxi & $\ldots$ & $\ldots$ & 1 & 1 & 1 & 1 & 29 & 2 & 4 & 1 & $\ldots$ & $\ldots$ & $\ldots$ & $\ldots$ & 40 \\
\hline Guangdong & 1 & 10 & $\ldots$ & $\ldots$ & $\ldots$ & $\ldots$ & 8 & $\ldots$ & $\ldots$ & $\ldots$ & $\ldots$ & $\ldots$ & $\ldots$ & $\ldots$ & 19 \\
\hline Zhejiang & $\ldots$ & 5 & $\ldots$ & $\ldots$ & $\ldots$ & $\ldots$ & 13 & $\ldots$ & $\ldots$ & $\ldots$ & 3 & $\ldots$ & $\ldots$ & $\ldots$ & 21 \\
\hline Guangxi & $\ldots$ & 2 & $\ldots$ & $\ldots$ & $\ldots$ & $\ldots$ & 4 & $\ldots$ & $\ldots$ & $\ldots$ & $\ldots$ & $\ldots$ & $\ldots$ & 1 & 7 \\
\hline Guizhou & $\ldots$ & 1 & $\ldots$ & $\ldots$ & $\ldots$ & $\ldots$ & 7 & $\ldots$ & $\ldots$ & $\ldots$ & $\ldots$ & $\ldots$ & $\ldots$ & $\ldots$ & 8 \\
\hline Chongqing & $\ldots$ & 2 & $\ldots$ & $\ldots$ & $\ldots$ & $\ldots$ & $\ldots$ & $\ldots$ & $\ldots$ & $\ldots$ & $\ldots$ & 1 & $\ldots$ & $\ldots$ & 3 \\
\hline Hubei & $\ldots$ & $\ldots$ & $\ldots$ & $\ldots$ & $\ldots$ & $\ldots$ & $\ldots$ & $\ldots$ & $\ldots$ & $\ldots$ & $\ldots$ & $\ldots$ & 3 & $\ldots$ & 3 \\
\hline Hunan & $\ldots$ & $\ldots$ & $\ldots$ & $\ldots$ & $\ldots$ & $\ldots$ & 2 & $\ldots$ & $\ldots$ & $\ldots$ & $\ldots$ & $\ldots$ & $\ldots$ & $\ldots$ & 2 \\
\hline Fujian & $\ldots$ & $\ldots$ & $\ldots$ & $\ldots$ & $\ldots$ & $\ldots$ & 2 & $\ldots$ & $\ldots$ & $\ldots$ & $\ldots$ & $\ldots$ & $\ldots$ & $\ldots$ & 2 \\
\hline Totaly & 1 & 20 & 1 & 1 & 1 & 1 & 65 & 2 & 4 & 1 & 3 & 1 & 3 & 1 & 105 \\
\hline Percent $^{\mathrm{z}}$ & 1.0 & 19.0 & 1.0 & 1.0 & 1.0 & 1.0 & 61.9 & 1.9 & 3.8 & 1.0 & 2.9 & 1.0 & 2.9 & 1.0 & $\ldots$ \\
\hline
\end{tabular}

${ }^{\mathrm{w}}$ Number of isolates belonging to each genotype in each province.

$x$ Total number of the isolates from each province.

$\mathrm{y}$ Total number of each genotype in 105 collected strains in China.

${ }^{\mathrm{z}}$ Genotypes in percentage of 105 collected strains in China.

Table 3. Numbers and genotypes of Xanthomonas citri subsp. citri strains in different citrus varieties

\begin{tabular}{|c|c|c|c|c|c|c|c|}
\hline \multirow[b]{2}{*}{ Genotype } & \multicolumn{6}{|c|}{ Citrus varieties } & \multirow[b]{2}{*}{ Total } \\
\hline & Citrus sinensis & C. reticulata & C.paradisi & C. unshiu & Fortunella margarita & Poncirus trifoliata & \\
\hline A & $\ldots$ & $\ldots$ & 1 & $\ldots$ & $\ldots$ & $\ldots$ & 1 \\
\hline $\mathrm{B}$ & 10 & 10 & $\ldots$ & $\ldots$ & $\ldots$ & $\ldots$ & 20 \\
\hline $\mathrm{C}$ & 1 & $\ldots$ & $\ldots$ & $\ldots$ & $\ldots$ & $\ldots$ & 1 \\
\hline $\mathrm{D}$ & 1 & $\ldots$ & $\ldots$ & $\ldots$ & $\ldots$ & $\ldots$ & 1 \\
\hline E & 1 & $\ldots$ & $\ldots$ & $\ldots$ & $\ldots$ & $\ldots$ & 1 \\
\hline F & 1 & $\ldots$ & $\ldots$ & $\ldots$ & $\ldots$ & $\ldots$ & 1 \\
\hline $\mathrm{G}$ & 50 & 7 & 2 & 4 & 1 & 1 & 65 \\
\hline $\mathrm{H}$ & 2 & $\ldots$ & $\ldots$ & $\ldots$ & $\ldots$ & $\ldots$ & 2 \\
\hline I & 3 & $\ldots$ & 1 & $\ldots$ & $\ldots$ & $\ldots$ & 4 \\
\hline $\mathrm{J}$ & 1 & $\ldots$ & $\ldots$ & $\ldots$ & $\ldots$ & $\ldots$ & 1 \\
\hline $\mathrm{K}$ & 1 & $\ldots$ & 2 & $\ldots$ & $\ldots$ & $\ldots$ & 3 \\
\hline $\mathrm{L}$ & 1 & $\ldots$ & $\ldots$ & $\ldots$ & $\ldots$ & $\ldots$ & 1 \\
\hline $\mathrm{M}$ & 3 & $\ldots$ & $\ldots$ & $\ldots$ & $\ldots$ & $\ldots$ & 3 \\
\hline $\mathrm{N}$ & $\ldots$ & $\ldots$ & $\ldots$ & $\ldots$ & 1 & $\ldots$ & 1 \\
\hline Total & $75(71.43 \%)$ & $17(16.19 \%)$ & $6(5.71 \%)$ & $4(3.81 \%)$ & $2(1.91 \%)$ & $1(0.95 \%)$ & 105 \\
\hline
\end{tabular}


belonged to 12 genotypes, excluding $\mathrm{A}$ and $\mathrm{N}$ (Table 3 ). The strains assigned to genotype $\mathrm{G}$ were distributed in seven provinces (excluding Hubei and Chongqing) and were associated with $C$. sinensis, $C$. reticulata, $C$. paradisi, $C$. unshiu, $F$. margarita, and $P$. trifoliata. These results suggest that genotype $\mathrm{G}$, which represents $61.9 \%$ of the total strains used in this study, is the dominant genotype in China, followed by genotype B (Tables 2 and 3). Interestingly, the strains collected from Jiangxi exhibited more diversity than those collected from other provinces (Table 2).

Identification of Chinese strains potentially lacking pthA. The pthA gene is essential for the pathogenicity of $X$. citri subsp. citri group A strains $(1,41)$. Interestingly, when $X$. citri subsp. citri strains 029-1, 029-2, and 049 (genotypes I, J, and L, respectively) were hybridized with the pthA probe, there was no evidence of a 3.4-kb pthA homologue (Figs. 2 and 3), suggesting that these strains are novel. In contrast, 11 genotypes of $X$. citri subsp. citri strains contained a 3.4-kb pthA homologue (Figs. 2 and 3). Strain 029-1 (genotype I) and the other 102 strains caused typical symptoms of CBC (Table 1) when inoculated to grapefruit and sweet orange. However, strains 029-2 and 049, representing genotypes J and $\mathrm{L}$, respectively, showed attenuated virulence and reduced bacterial growth in planta (Table 1; Fig. 4).

pthA restores full virulence to genotypes lacking a pthA-sized gene. We speculated that the attenuated virulence of strains 029-2 and 049 might be due to the absence of a 3.4-kb pthA homologue. When pPthA was transferred into these strains, 029-2(pPthA) and 049(pPthA) caused symptoms of CBC comparable with strain 025 (Fig. 4A), which contains a $p$ thA homologue. In these experiments, the wild-type $X$. citri subsp. citri strains 049 and 029-2 showed weak virulence and reduced water-soaking in both sweet orange and grapefruit (Fig. 4A). Bacterial growth in planta was evaluated by plating inoculated leaves to NA. At each time point, the population of 029-2(pPthA) and 049(pPthA) was equivalent to 025 and 029-1 in grapefruit and sweet orange (data not shown). However, the 029-2 and 049 population was significantly lower than 025 and $029-1$ (Fig. $4 \mathrm{~B}$ and $\mathrm{C})$; the latter two strains either contain a 3.4-kb pthA-sized gene (strain 025) or a potential pthA homologue (strain 029-1). Thus, the results demonstrate that the introduction of $p t h A$ restored a full level of virulence to 029-2 and 049 when introduced in trans.

\section{Discussion}

In this report, we describe tale-based genetic diversity in bacterial strains causing $\mathrm{CBC}$ isolated from nine citrus-growing provinces in southern China. In all, 105 strains (Table 1) were classified into 14 genotypes (A to $\mathrm{N}$ ) based on the size and number of pthA homologues. The majority of strains were assigned to genotype $\mathrm{G}$ (Tables 2 and 3). In general, four to six potential tale genes were present in Chinese strains based on Southern blot hybridizations using the internal $S p h$ I fragment of $p t h A$ as a probe (Table 1; Figs. 2 and 3). The importance of $p t h A$ in symptomology and bacterial growth has been previously established. Previously, $p t h A$ mutants of strains 3213 and KC21 exhibited decreased symptom severity and bacterial growth on citrus, which indicates that $p t h A$ plays a critical role in conferring virulence (38).

Southern blot analysis revealed that genotypes $\mathrm{J}$ and $\mathrm{L}$ lacked a hybridizing fragment representing the size of pthA (e.g. a 3.4-kb

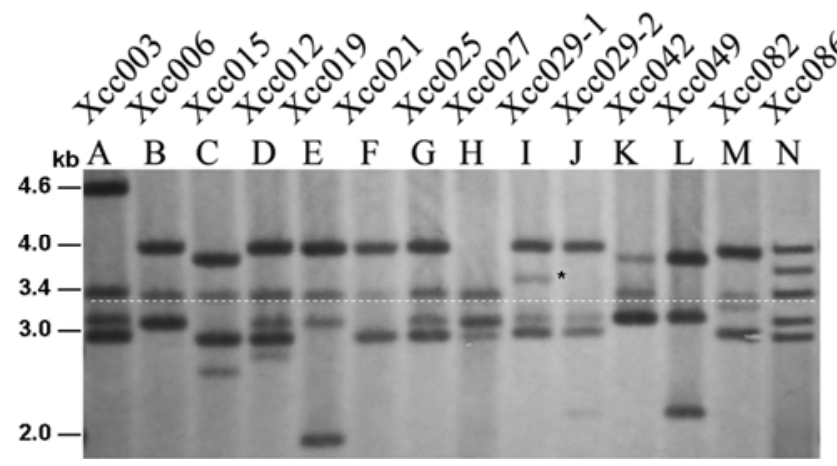

Fig. 3. Southern blot analysis of the 14 genotypes Xanthomonas citri pv. citri strains identified in Figure 2. Genomic DNA of the 14 genotypes was digested with BamHI and hybridized with a 2.3-kb internal Sphl fragment containing the central repeat region of pthA (Fig. 1). Hybridized bands underlined by a dashed white line stand for transcriptional activator-like effector (tale) genes, possibly homologous to pthA in the same size. The band with an asterisk (*) marker indicates a pthA homologue which may be a 102-bp repeat unit larger than pthA. The assay was repeated twice and representative results are shown.

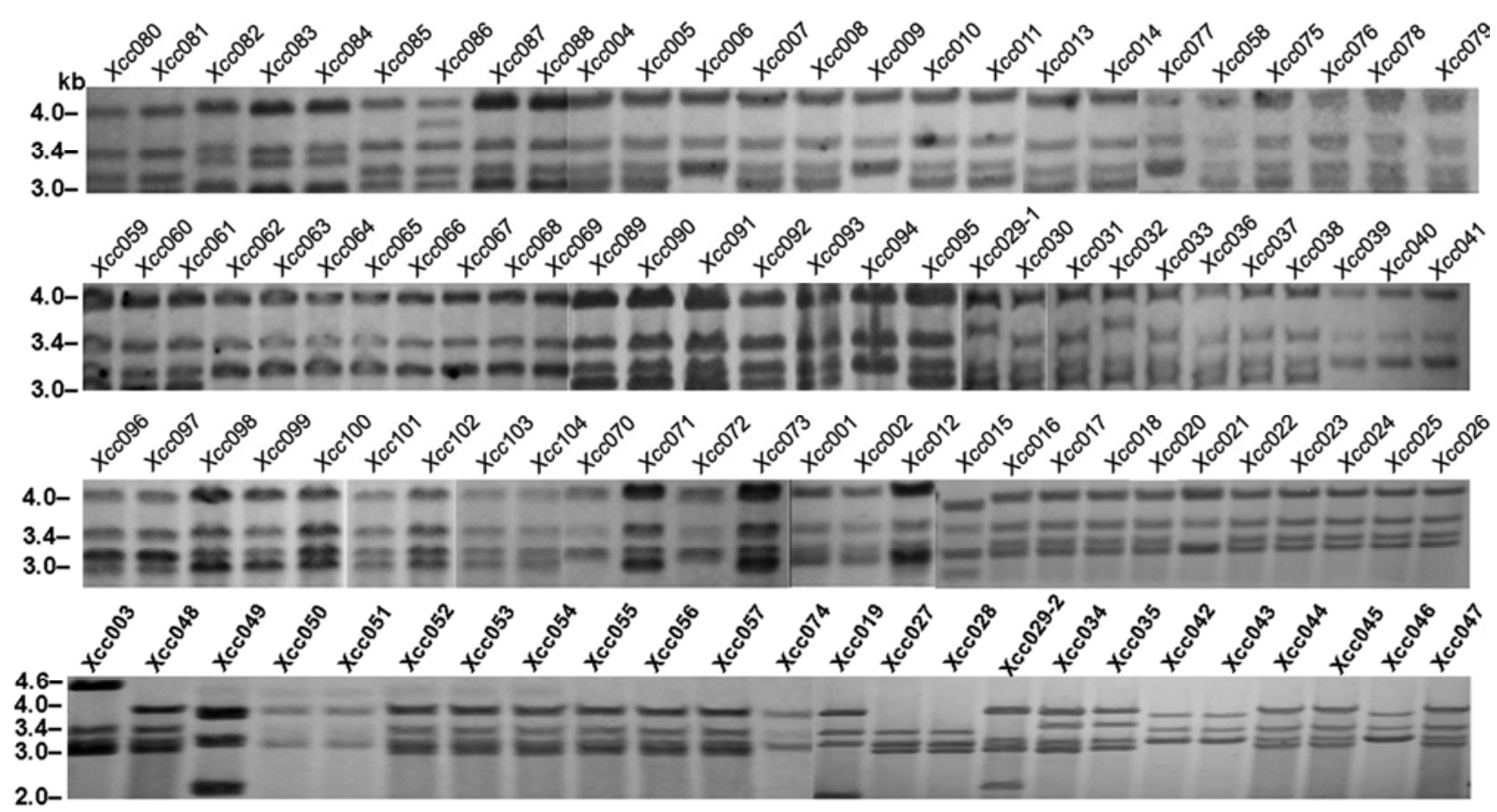

Fig. 2. Southern bot analysis of potential transcriptional activator-like effector (tale) genes in 105 strains of Xanthomonas citri pv. citri. Genomic DNA of the strains was digested with BamHI and hybridized with an internal Sphl fragment of pthA (Fig. 1). Numbers to the left of the lanes indicate the size of hybridizing bands (kb). Southern blot assays were repeated three times with similar results. 
Bam $\mathrm{HI}$ fragment). The two strains in genotypes $\mathrm{J}$ and $\mathrm{L}(029-2$ and 049, respectively) were attenuated in their ability to induce CBC symptoms and showed reduced growth in planta when compared with other genotypes. A high level of virulence (e.g., increased symptom severity and higher growth in planta) was conferred to strains 029-2 and 049 when the pthA gene was introduced in trans
(Fig. 4). These results further support the role of $p t h A$ as a major virulence effector in $X$. citri subsp. citri.

Pathotypes of X. citri pv. citri have been previously described with a very narrow host range. For example, the host range of pathotypes $\mathrm{A}^{\mathrm{w}}$ from Florida and $\mathrm{A}^{*}$ from southwest Asia is restricted to Mexican lime (C. aurantifolia) $(39,45)$. Grapefruit $(C$.
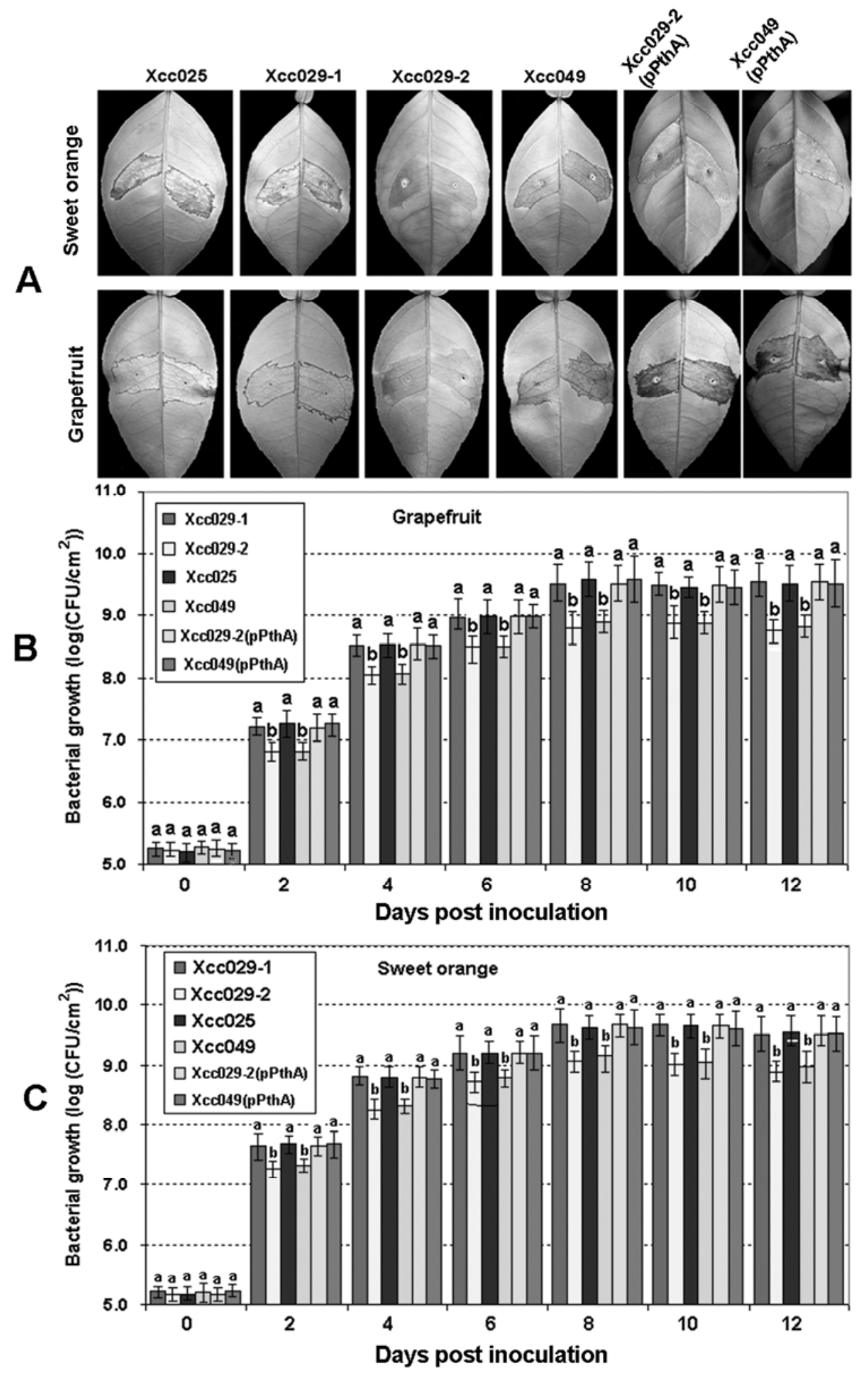

Fig. 4. Virulence analysis and bacterial growth of Xanthomonas citri pv. citri strains in grapefruit and sweet orange. A, Symptoms induced by $X$. citri pv. citri strains 025 , $029-$ $1,029-2,049,029-2(\mathrm{pPthA})$, and 049(pPthA). Bacterial suspensions (approximately at $1 \times 10^{8} \mathrm{CFU} / \mathrm{ml}$ ) were infiltrated into citrus leaves using a needleless syringe, and symptoms were recorded 12 days post inoculation. $\mathbf{B}$ and $\mathbf{C}$, Bacterial growth in grapefruit and sweet orange. Numbers represent CFU per square centimeter in leaf tissue at $0,2,4,6,8,10$, and 12 days after inoculation with strains 025, 029-1, 029-2, 049, 029-2(pPthA), and 049(pPthA). Data represent the mean \pm the standard deviation from three replicates, each containing three leaves. Columns labeled with different letters represent significant differences $(P=0.01, t$ test) between the tested strains. 
paradisi) can serve as a differential host for $\mathrm{A}^{\mathrm{w}}$ strains; this pathotype elicits a strong HR on grapefruit, whereas $A^{*}$ strains show reduced symptoms or fail to elicit an HR on this host (6). In the present study, assays for the HR and pathogenicity indicated that the $105 \mathrm{CBC}$ strains did not include $\mathrm{A}^{\mathrm{w}}$ and $\mathrm{A}^{*}$ pathotypes. This conclusion is based on the absence of strains triggering an HR in grapefruit or showing attenuated symptoms on this host.

In the present study, we were not able to unequivocally confirm that the 3.4-kb hybridizing band in 102 of the strains was pthA. However, the results do suggest that all strains contain multiple tale genes, which likely contain different numbers of repeat units and RVDs. The largest (4.6-kb BamHI fragment in genotype A) and smallest (2.0-kb BamHI fragment in genotype E) pthA homologues could potentially contain 29 and 8 RVDs, respectively, based on the conserved, structural properties of TALEs (Fig. 1), although confirmation by sequence analysis is needed. Our results also suggest that some of the tale genes may be redundant; for example, the genotype $\mathrm{H}$ strain (X. citri subsp. citri 027$)$ did not contain a 4.0-kb pthA homologue (Figs. 2 and 3 ) but showed full virulence in the tested host plants (Table 1). A new screening or assessment approach may be required to precisely define the roles of these different tale genes. In the related pathogen, $X$. oryzae pv. oryzae, TALEs with substantial effects on virulence were shown to activate members of the OSSWEET family of sucrose transporter genes (7) to promote disease. In a recent study, a TALE-free strain of $X$. oryzae was used to dissect the function of individual TALEs on rice cultivars (44), a promising approach that could also be used for X. citri.

Further study of the tale genes in X. citri subsp. citri may reveal an evolutionary interaction with citrus host plants. The tale-based diversity of Chinese strains may be more complex than CBC strains isolated from Korea (25), India (45), and others citrusgrowing regions (27). Genomic sequencing of the Asian group A strain 306 (10) and our X. citri subsp. citri strain 029-1 (unpublished data) indicate that tale genes are plasmid borne in $X$. citri subsp. citri, indicating that horizontal gene transfer and homologous recombination could easily occur in tale loci and result in new tale genes that improve pathogen fitness (46). A pthA-homologous gene in 029-1, possibly a repeat unit larger than pthA (Figs. 2 and 3), may act similarly to $p t h A$ as a major virulence effector. We assume that the RVDs in this TALE may be different from that of PthA.

We acknowledge that the genetic diversity reported herein is not a comprehensive sampling of what might reside throughout the whole citrus-growing regions in China. Nonetheless, the present study indicates that the majority of CBC strains could be assigned to the $\mathrm{G}$ genotype (Tables 1-3) and four to six potential tale genes were present in strains (Table 1; Figs. 2 and 3). The strains and genotypes defined in this study will be useful in designing future studies aimed at defining genetic diversity in newly isolated strains of CBC.

\section{Acknowledgments}

This work was supported by the National Natural Science Foundation of China (31230059), the Special Fund for Agro-Scientific Research in the Public Interest (201003067-09), and the National Science and Technology Project (2007BAD61B05). We thank Y.-P. Duan at the United States Department of Agriculture for providing plasmid pZit45, C.-X. Chen at the Fruit Protection Station for CBC sample collection in Jiangxi province, and the Department of Agriculture of China for official permission to collect CBC samples from citrusgrowing regions in China.

\section{Literature Cited}

1. Al-Saadi, A., Reddy, J. D., Duan, Y. P., Brunings, A. M., Yuan, Q., and Gabriel, D. W. 2007. All five host-range variants of Xanthomonas citri carry one pthA homolog with 17.5 repeats that determines pathogenicity on citrus, but none determine host-range variation. Mol. Plant-Microbe Interact. 20:934-943.

2. Antony, G., Zhou, J., Huang, S., Li, T., Liu, B., White, F., and Yang, B. 2011. Rice xa13 recessive resistance to bacterial blight is defeated by induction of the disease susceptibility gene Os-11N3. Plant Cell 22:3864-3876.

3. Ausubel, F. M., Brent, R., Kingston, R. E., Moore, D. D., Seidman, J. G., Smith, J. A., and Struhl, K. 1995. Current Protocols in Molecular Biology.
John Wiley \& Sons, New York.

4. Boch, J., Scholze, H., Schornack, S., Landgraf, A., Hahn, S., Kay, S., Lahaye, T., Nickstadt, A., and Bonas, U. 2009. Breaking the code of DNA binding specificity of TAL-type III effectors. Science 326:1509-1512.

5. Bonas, U., Stall, R. E., and Staskawicz, B. 1989. Genetic and structural characterization of the avirulence gene avrBs3 from Xanthomonas campestris pv. vesicatoria. Mol. Gen. Genet. 218:127-136.

6. Brunings, A. M., and Gabriel, D. W. 2003. Xanthomonas citri: breaking the surface. Mol. Plant Pathol. 4:141-157.

7. Chen, L. Q., Hou, B. H., Lalonde, S., Takanaga, H., Hartung, M. L., Qu, X. Q., Guo, W. J., Kim, J. G., Underwood, W., Chaudhuri, B., Chermak, D., Antony, G., White, F. F., Somerville, S. C., Mudgett, M. B., and Frommer, W. B. 2010. Sugar transporters for intercellular exchange and nutrition of pathogens. Nature 468:527-532.

8. Cubero, J., and Graham, J. H. 2002. Genetic relationship among worldwide strains of Xanthomonas causing canker in citrus species and design of new primers for their identification by PCR. Appl. Environ. Microbiol. 68:12571264.

9. Das, A. K. 2003. Citrus canker-a review. J. Appl. Hortic. 5:52-60.

10. Da Silva, A. C. R., Ferro, J. A., Reinach, F. C., Farah, C. S., Furlan, L. R. Quaggio, R. B., Monteiro-Vitorello, C. B., Van Sluys, M. A., Almeida, N. F., Alves, L. M. C., Amaral, A. M., Bertolini, M. C., Camargo, L. E. A., Camarotte, G., Cannavan, F., Cardozo, J., Chambergo, F., Ciapina, L. P., Cicarelli, R. M. B., Coutinho, L. L., Cursino-Santos, J. R., El-Dorry, H., Faria, J. B., Ferreira, A. J. S., Ferreira, R. C. C., Ferro, M. I. T., Formighieri, E. F., Franco, M. C., Greggio, C. C., Gruber, A., Katsuyama, A. M., Kishi, L. T., Leite, R. P., Lemos, E. G. M., Lemos, M. V. F., Locali, E. C., Machado, M. A., Madeira, A. M. B. N., Martinez-Rossi, N. M., Martins, E. C., Meidanis, J., Menck, C. F. M., Miyaki, C. Y., Moon, D. H., Moreira, L. M., Novo, M. T. M., Okura, V. K., Oliveira, M. C., Oliveira, V. R., Pereira, H. A., Rossi, A., Sena, J. A. D., Silva, C., De Souza, R. F., Spinola, L. A. F., Takita, M. A., Tamura, R. E., Teixeira, E. C., Tezza, R. I. D. Trindade dos Santos, M., Truffi, D., Tsai, S. M., White, F. F., Setubal, J. C., and Kitajima, J. P. 2002. Comparison of the genomes of two Xanthomonas pathogens with differing host specificities. Nature 417:459-463.

11. Deng, D., Yan, C., Pan, X., Mahfouz, M., Wang, J., Zhu, J. K., Shi, Y., and Yan, N. 2012. Structural basis for sequence-specific recognition of DNA by TAL effectors. Science 335:720-723.

12. Duan, Y. P., Castaneda, A., Zhao, G., Erdos, G., and Gabriel, D. W. 1999. Expression of a single, host-specific, bacterial pathogenicity gene in plant cells elicits division, enlargement, and cell death. Mol. Plant-Microbe Interact. 12:556-560.

13. Dye, D. W., Bradbury, J. F., Goto, M., Hayward, A. C., Lelliot, R. A., and Schroth, M. N. 1980. International standards for naming pathovars of phytopathogenic bacteria and a list of pathovar names and pathotype strains. Rev. Plant Pathol. 59:153-168.

14. Fawcett, H. S., and Jenkins, A. E. 1933. Records of citrus canker from herbarium specimens of the genus Citrus in England and the United States. Phytopathology 23:820-824.

15. Egel, D. S., Graham, J. H., and Stall, R. E. 1991. Genomic Relatedness of Xanthomonas campestris strains causing diseases of citrus. Appl. Environ. Microbiol. 57:2724-2730.

16. Gabriel, D., Hunter, G., Kingsley, M., Miller, J., and Lazo, G. 1988. Clonal population structure of Xanthomonas campestris and genetic diversity among citrus canker strains. Mol. Plant-Microbe Interact. 1:59-65.

17. Gottwald, T. R., Graham, J. H., and Schubert, T. S. 2002. Citrus canker: The pathogen and its impact. Plant Health Prog. Online publication. doi:10.1094/PHP-2002-0812-01-RV

18. Graham, J. H., Gottwald, T. R., Cubero, J., and Achor, D. S. 2004. Xanthomonas axonopodis pv. citri: Factors affecting successful eradication of citrus canker. Mol. Plant Pathol. 5:1-15.

19. Graham, J. H., Hartung, J. S., Stall, R. E., and Chase, A. R. 1990. Pathological, restriction-fragment length polymorphism, and fatty acid profile relationship between Xanthomonas campestris from citrus and noncitrus hosts. Phytopathology 80:829-836.

20. Hartung, J. S. 1992. Plasmid-based hybridization probes for detection and identification of Xanthomonas campestris pv. citri. Plant Dis. 76:889-893.

21. Hasse, C. H. 1915. Pseudomonas citri, the cause of citrus canker. J. Agric. Res. 4:97-100.

22. Lahaye, T., and Bonas, U. 2001. Molecular secrets of bacterial type III effector proteins. Trends Plant Sci. 6:479-485.

23. Lee, B. M., Park, Y. J., Park, D. S., Kang, H. W., Kim, J. G., Song, E. S., Park, I. C., Yoon, U. H., Hahn, J. H., Koo, B. S., Lee, G. B., Kim, H., Park, H. S., Yoon, K. O., Kim, J. H., Jung, C. H., Koh, N. H., Seo, J. S., and Go, S. J. 2005. The genome sequence of Xanthomonas oryzae pathovar oryzae KACC10331, the bacterial blight pathogen of rice. Nucleic Acids Res. 33:577-568.

24. Lee, H. A. 1918. Further data on the susceptibility of rutaceous plants to citrus canker. J. Agric. Res. 15:661-666.

25. Lee, S., Lee, J., Lee, D. H., and Lee, Y. H. 2008. Diversity of pthA Gene of Xanthomonas strains causing citrus bacterial canker and its relationship with virulence. Plant Pathol. J. 24:357-360.

26. Li, J. Y., and Wang, N. 2012. The gpsX gene encoding a glycosyltransferase is important for polysaccharide production and required for full virulence in 
Xanthomonas citri subsp. citri. BMC Microbiol. 12:31.

27. Li, W., Song, Q., Brlansky, R. H., and Hartung, J. S. 2007. Genetic diversity of citrus bacterial canker pathogens preserved in herbarium specimens. Proc. Natl. Acad. Sci. USA 104:18427-18432.

28. Li, Y. R., Che, Y. Z., Zou, H. S., Cui, Y. P., Guo, W., Zou, L. F., Biddle, E. M., Yang, C. H., and Chen, G. Y. 2011. Hpa2 is required by HrpF to translocate Xanthomonas oryzae TAL effectors into rice for pathogenicity. Appl. Environ. Microbiol. 77:3809-3818.

29. Louws, F. J., Fulbright, D. W., Stephens, C. T., and de Bruijn., F. J. 1994. Specific genomic fingerprints of phytopathogenic Xanthomonas and Pseudomonas pathovars and strain generated with repetitive sequences and PCR. Appl. Environ. Microbiol. 60:2286-2295.

30. Mak, A. N., Bradley, P., Cernadas, R. A., Bogdanove, A. J., and Stoddard, B. L. 2012. The crystal structure of TAL effector PthXo1 bound to its DNA target. Science 335:716-719.

31. Moscou, M. J., and Bogdanove, A. J. 2009. A simple cipher governs DNA recognition by TAL effectors. Science 326:1501

32. Ponciano, G., Ishihara H., Tsuyumu, S., and Leach, J. E. 2003. Bacterial effectors in plant disease and defense: keys to durable resistance? Plant Dis. $87: 1272-1282$

33. Pruvost, O., Hartung, J. S., Civerolo, E. L., Dubios, C., and Perrier, X. 1992. Plasmid DNA fingerprints distinguish pathotypes of Xanthomonas campestris pv. citri, the casual agent of citrus bacterial canker disease. Phytopathology 82:485-490.

34. Rigano, L. A., Marano, M. R., Castagnaro, A. P., Do Amaral, A. M., and Vojnov, A. A. 2010. Rapid and sensitive detection of citrus bacterial canker by loop-mediated isothermal amplification combined with simple visual evaluation methods. BMC Microbiol. 10:176-173.

35. Schaad, N. W., Postnikova, E., Lacy, G., Sechler, A., Agarkova, I., Stormberg, P. E., Stormberg, V. K., and Vidaver, A. K. 2005. Reclassification of Xanthomonas campestris pv. citri (ex Hasse 1915) Dye 1978 forms A, $\mathrm{B} / \mathrm{C} / \mathrm{D}$, and $\mathrm{E}$ as $X$. smithii subsp. citri (ex Hasse) sp. nov. nom. rev. comb. nov., X. fuscans subsp. aurantifolii (ex Gabriel 1989) sp. nov. nom. rev. comb. nov., and X. alfalfae subsp. citrumelo (ex Riker and Jones) Gabriel et al., 1989 sp. nov. nom. rev. comb. nov.; X. campestris pv. malvacearum (ex Smith 1901) Dye 1978 as X. smithii subsp. smithii nov. comb. nov. nom. nov.; X. campestris pv. alfalfae (ex Riker and Jones,1935) Dye 1978 as X. alfalfae subsp. alfalfae (ex Riker et al., 1935) sp. nov. nom. rev.; and "var. fuscans" of X. campestris pv. phaseoli (ex Smith, 1987) Dye 1978 as X. fuscans subsp. fuscans sp. nov. Syst. Appl. Microbiol. 28:494-518

36. Schaad, N. W., Postnikova, E., Lacy, G., Sechler, A., Agarkova, I., Stromberg, P. E., Stromberg, V. K., and Vidaver, A. K. 2006. Emended classification of xanthomonad pathogens on citrus. Syst. Appl. Microbiol. 29:690-695.

37. Schubert, T. S., and Miller, J. W. 1996. Bacterial citrus canker. Pages 110111 in: Plant Pathology Circular Volume 377. Florida Department of Agri- culture and Consumer Services DoPI, Gainesville.

38. Shiotani, H., Fujikawa, T., Ishihara, H., Tsuyumu, S., and Ozaki, K. 2007. A pthA homolog from Xanthomonas axonopodis pv. citri responsible for hostspecific suppression of virulence. J. Bacteriol. 189:3271-3279.

39. Sun, X. A., Stall, R. E., Jones, J. B., Cubero, J., Gottwald, T. R., Graham, J. H., Dixon, W. N., Schubert, T. S., Chaloux, P. H., Stromberg, V. K., Lacy, G. H., and Sutton, B. D. 2004. Detection and characterization of a new strain of citrus canker bacteria from key Mexican lime and Alemow in South Florida. Plant Dis. 88:1179-1188.

40. Swarup, S., De Feyter, R., Brlansky, R. H., and Gabriel, D. W. 1991. A pathogenicity locus from Xanthomonas citri enables strains from several pathovars of Xanthomonas campestris to elicit canker-like lesions on citrus. Phytopathology 81:802-809.

41. Swarup, S., Yang, Y., Kingsley, M. T., and Gabriel, D. W. 1992. An Xanthomonas citri pathogenicity gene, pthA, pleiotropically encodes gratuitous avirulence on nonhosts. Mol. Plant-Microbe Interact. 5:204-213.

42. Vauterin, L., Hoste, B., Kersters, K., and Swings, J. 1995. Reclassification of Xanthomonas. Int. J. Syst. Bacteriol. 45:472-489.

43. Vauterin, L., Yang, P., Hoste, B., Vancanneyt, M., Civerolo, E. L., Swings, J., and Kersters, K. 1991. Differentiation of Xanthomonas campestris pv. citri strains by sodium dodecyl sulfate-polyacrylamide gel electrophoresis of proteins, fatty acid analysis, and DNA-DNA hybridization. Int. J. Syst. Bacteriol. 41:535-542.

44. Verdier, V., Triplett, L. R., Hummel, A. W., Corral, R., Cernadas, R. A., Schmidt, C. L., Bogdanove, A. J., and Leach, J. E. 2012. Transcription activator-like (TAL) effectors targeting OsSWEET genes enhance virulence on diverse rice (Oryza sativa) varieties when expressed individually in a TAL effector-deficient strain of Xanthomonas oryzae. New Phytol. 196:11971207.

45. Verniere, C., Hartung, J. S., Pruvost, O. P., Civerolo, E. L., Alvarez, A. M., Maestri, P., and Luisetti, J. 1998. Characterization of phenotypically distinct strains of Xanthomonas axonopodis pv. citri from Southwest Asia. Eur. J. Plant Pathol. 104:477-487.

46. Wu, X. M., Li, Y. R., Zou, L. F., and Chen, G. Y. 2007. Gene-for-gene relationships between rice and diverse avrBs3/pthA avirulence genes in Xan thomonas oryzae pv. oryzae. Plant Pathol. 56:26-34.

47. Yan, Q., and Wang, N. 2011. The ColR/ColS two-component system plays multiple roles in the pathogenicity of the citrus canker pathogen Xanthomonas citri subsp. citri. J. Bacteriol. 193:1590-1599.

48. Yang, Y. N., and Gabriel, D. W. 1995. Xanthomonas avirulence/ pathogenicity gene family encodes functional plant nuclear targeting signals. Mol. Plant-Microbe Interact. 8:627-631.

49. Young, J. M., Dye, D. W., Bradbury, J. F., Panagopoulos, C. G., and Robbs, C. F. 1978. A proposed nomenclature and classification for plant pathogenic bacteria. N.Z. J. Agric. Res. 21:153-177. 